\title{
Richard Madsen, Democracy's Dharma: Religious Renaissance and Political Development in Taiwan.
} Berkeley: University of California Press, 2007.

David A. Palmer

\section{OpenEdition}

\section{Journals}

Electronic version

URL: http://journals.openedition.org/chinaperspectives/4947

DOI: 10.4000/chinaperspectives.4947

ISSN: 1996-4617

Publisher

Centre d'étude français sur la Chine contemporaine

Printed version

Date of publication: 31 December 2009

ISSN: 2070-3449

Electronic reference

David A. Palmer, «Richard Madsen, Democracy's Dharma: Religious Renaissance and Political Development in Taiwan. », China Perspectives [Online], 2009/4 | 2009, Online since 13 January 2010, connection on 24 September 2020. URL : http://journals.openedition.org/chinaperspectives/4947 ; DOI : https://doi.org/10.4000/chinaperspectives.4947

This text was automatically generated on 24 September 2020

(c) All rights reserved 


\title{
Richard Madsen, Democracy's Dharma: Religious Renaissance and Political Development in Taiwan.
}

\author{
Berkeley: University of California Press, 2007.
}

\author{
David A. Palmer
}

Democracy's Dharma is a study of how the "religious renaissance" in Taiwan since the lifting of martial law in 1987, has contributed to the development and stability of Taiwanese democracy. The author, Richard Madsen, offers the rare perspective of a former Catholic missionary to Taiwan who later became a sociologist and a recognized authority on American civil society and public life (Habits of the Heart, 1985; the Good Society, 1991), on revolutionary morality and social transformation in the Peoples' Republic of China (Morality and Power in a Chinese Village, 1984 and Chen Village, 1992), and on religion and civil society in the Chinese world (China's Catholics, 1998). All of these works reflect a search for the moral foundations of civilized social life, and a critique of a purely secular liberalism which sees society as "founded simply on the rational self-interest of individual citizens." (p. xxiii). But while the universality and inevitability of the secular liberal paradigm has been undermined by the momentous rise of religious movements around the world in the past few decades, many such movements, such as the crusading and jihadist fundamentalisms found in the Christian and Muslim worlds, have been causes and justifications for ethnic conflict, culture wars, imperialist aggression, and destructive terrorism. It is such movements, often socially destructive, which have dominated most of the recent discourse on religion and society. In Democracy's Dharma, Madsen shows an alternative scenario in Taiwan, in which religious movements appear to make positive contributions to the growth of a healthy and flourishing democracy and to its harmonious integration into the world community, under strongly adverse conditions: the lack of an indigenous democratic tradition and the immaturity of its institutions, and, owing to the ambiguous and contested sovereign status of the Taiwanese state, the absence of a fully-formed nationstate able to incarnate the moral aspirations of the people within the family of nations. Pleasantly surprised by his experience of the new Buddhist and Daoist movements - 
Tzu Chi (Ciji), Buddha's Light Mountain (Foguangshan), Dharma Drum Mountain (Fagushan), and the Daoist Enacting Heaven Temple (Xingtiangong) which he investigated through ethnographic participant-observation in 1999 and later follow-up visits, Madsen aims to convey "hope that the progressive promises of religion will overcome the regressive perils of religion in the modern world" (xxiii, italics in original).

2 The book is short, elegantly written, and simply structured: an introductory chapter on the Taiwanese religious context, one chapter for each of the four groups studied, and a concluding chapter. The material on the four groups will be familiar to specialists of contemporary Chinese religious movements - the three Buddhist movements, and Tzu Chi in particular, have already been the subject of several academic studies, including two previously published in this journal. ${ }^{1}$ Madsen's contribution lies in the way he compares the groups with the fine eye of a cultural sociologist, and considers how they fit into the context of Taiwan's democratic development, and even the course of world religious history. As such, the book will appeal to a wider range of readers than the other studies.

3 The four groups studied, particularly the three Buddhist ones, are among the largest non-governmental organizations in Taiwan, claiming millions of members and operating branches in several countries. They are "modern" religious organizations in the sense that they are based on voluntary adhesion rather than the ascriptive, customary membership of traditional groups. Although they have a core of monks, nuns and priests, their membership is primarily made up of laypeople who are efficiently organized to carry out volunteer, public service and administrative tasks. They own extensive financial assets (reaching the billions of dollars) and properties (including universities and hospitals). They are highly adept in the use of modern media, operating high-quality newspapers, magazines, websites, and TV stations.

4 Although nominally Buddhist or Daoist, the groups share a common "Confucian" core expressed as a commitment to this-worldly self-cultivation, upholding the family virtues of filial piety (xiao), and nurturing social harmony - values which are given new meaning in the context of modern, middle-class lives. Indeed, the groups give expression to the spiritual and social yearnings of Taiwan's new middle class - and each is associated with one particular segment of that class: the lower middle class of shopkeepers, clerical workers and retail clerks for the Enacting Heaven Temple; affluent business owners, government officials and politicians for Foguangshan; modern managers and service professionals for Tzu Chi; and intellectuals for Fagushan.

5 All the groups combine the local lore, traditions and symbols which are familiar to anyone growing up in Taiwan, with a more transcendent, universalist and cosmopolitan orientation. As a result, they contribute to articulating a positive, "ecumenical" expression of Taiwanese identity, in contrast to the divisive formulations advocated by the parties confronting each other in the political sphere. Since the Taiwanese state is not recognized within the global society of nations, it cannot fully incarnate the collective aspirations of the Taiwanese people; while the four religious groups, with their transnational networks of followers, their relief and philanthropic operations in China and abroad, and their contacts with foreign governments and dignitaries, act as emissaries of a benevolent Taiwanese identity on the world stage.

6 For Madsen, the Taiwanese religious groups demonstrate the fallacy of the secularism of liberal political theory, which posits that a healthy democracy rests on an enlightened citizenry freed from the mental shackes of religious mythology, and on a 
civil society which asserts its independence vis-à-vis the state and keeps the state in check. The Taiwanese religious movements, however, have grown and acquired mass followings in parallel with the process of Taiwan's democratization, but, while maintaining their autonomy through rootedness in their spiritual principles, they have maintained cooperative relations with the Taiwanese government - in contrast with American churches which seek state funds to build religious schools, Tzu Chi uses its own funds to build public schools controlled by the government! But for Madsen, such close relationships do not indicate an unfinished stage of civil society development; rather, they have contributed to the consolidation of Taiwanese democracy by softening its "rough edges", by nurturing the volunteer engagement of citizens, and by providing a conservative force which has helped to stabilize a still young and fragile democracy.

7 Madsen even sees these groups as offering a beacon of hope to the world. On the one hand, secularism has failed and there is increasing recognition of the need for society to rest on shared sacred and moral foundations; on the other hand, most religious movements which, today, would claim to provide such foundations are divisive and dangerous for world peace. In Taiwan, however, we see the emergence of universalistic groups which, though rooted in local traditions, lead their followers to transcend particularistic divisions, to become aware of the unity of humankind, and to engage with other cultures and religions in a truly ecumenical spirit. These "moments of axial religious creativity" are thus models to be studied and emulated around the world: they should be investigated while they are still alive, so that we may cultivate similar "shoots of hope" in other times and places (p. 157). What Madsen is proposing, in effect, is a new agenda for research and action in the sociology of religion: what are the characteristics of the "new axial age" he suggests the Taiwanese groups are expressions of? If secularism is not a viable model for an emerging global society, then what type of "progressive" sacrality and religion is appropriate? What conditions facilitate the emergence of such progressive religious traits? And how can they be actively nurtured?

\section{NOTES}

1. André Laliberté, "Tzu Chi and the Buddhist Revival in Taiwan:

Rise of a new conservatism?" China Perspectives no. 19, 1998, pp. 44-50; David Schak and Hsin-Huang Michael Hsiao, "Taiwan's Socially Engaged Buddhist Groups", China Perspectives no. 59, 2005, http://chinaperspectives.revues.org/document2803.html. Accessed on 19 Oct. 2009. 